\title{
Globalization processes and their effects on the household economy
}

\author{
Jarmila Vidová ${ }^{1, *}$, Peter Sika $^{2}$ \\ ${ }^{1}$ University of Economics Bratislava, Faculty of National Economy, Department of Economic Policy, \\ Dolnozemská cesta 1, 85104 Bratislava, Slovakia \\ ${ }^{2}$ University of Economics Bratislava, Faculty of National Economy, Department of Social \\ Development and Labour, Dolnozemská cesta 1,851 04 Bratislava, Slovakia
}

\begin{abstract}
.
Research background: Globalization influences the behavior of all economic actors. The aim of the presented scientific article is to examine households and household economics, which is affected by current social and innovative changes. The role of households is very important in any economy, they support economic growth with their expenditures, and it depends not only on the growth rate of household consumption, but also on the large share of income of household expenditures.

Purpose of the article: The authors in the scientific article will examine households and their decision-making processes, which mainly concern consumption, taking into account income, expenditure, structure, savings, indebtedness and income stratification in the context of maintaining the required quality of life.

Methods: To meet the goal, we will use available data, we will use statistical methods to analyze, compare with each other and, based on the findings, propose the necessary measures.

Findings \& Value added: Globalization processes are part of us and must be accepted in order for households to be able to meet their needs. As their income in particular becomes important, it will be necessary to decide which group of expenditures the household will prefer in order to achieve them. So far, according to statistical data, a very low part of household expenditures went to education, although it is the higher educational level of household members that presupposes that the household will be able to adapt to the challenges of globalization.
\end{abstract}

Keywords: globalization; household; economy; income; consumption

JEL Classification: D10; D14; F60

\footnotetext{
* Corresponding author: jarmila.vidova@euba.sk
} 


\section{Introduction}

The process of globalization can be considered as the strongest factor influencing the development of the world economy in the period after the Second World War. Globalization brings new theoretical problems, leads experts to re-evaluate existing theoretical concepts and views on society and socio-economic processes [1-5]. Several authors consider globalization to be a growing economic interdependence of states on a global scale due to the growing volume and type of international transactions in goods and services and international capital flows, as well as the faster and wider diffusion of innovative technologies [1, 6-9]. Giddens defined globalization as "the intensification of social relations at the global level, which leads to the interconnection of very distant localities in such a way that local events are influenced by events that take place in distant places and vice versa [10]. According to Gray, globalization is a historical process based on the unequal economic level of the individual states of the world [11]. The growing interconnectedness of the world's economies is made possible by differences between regions, countries and their localities. Hagget defines globalization as the process by which events, activities and decisions made in one part of the world can have significant consequences for communities (states, social groups) in remote parts of the Earth [12].

Pichanič considers globalization to be a process that makes the world, its economic systems, national communities more uniform, more integrated and more interdependent [13]. According to Holton, the main significance of globalization is that it involves many different societal changes [14]. All of the above perceptions of globalization emphasize the interconnection of economies. In the process of globalization, national unity and its actors, transnational and transnational relations, new identities, social spaces, social states or processes intersect, thus globalization being positively reflected in some sectors, such as medicine, science and research. The market without borders has created more jobs, higher consumption, which in turn presupposes higher production, brings incentives for economic and social development, although not to the same extent for every economy, ie economic entity. In the process of globalization, the most gaining are those economic entities that have been able to make the best use of the competitive environment that this process creates and also influences the improvement of living conditions for people all over the world.

Low-income developing countries (LIDCs) have seen a sharp increase in economic integration since the early 1990 s, but this has affected inclusive growth and poverty alleviation. The benefits of globalization have been concentrated in households with quality human capital, which has led to higher income inequality [4]. Several researches show that income and wealth inequalities have increased in recent decades [15-17]. Uneven income disparities, which have increased between the $20 \%$ of the world's poorest and $20 \%$ of the world's richest people since the late 1960s. 2.4 billion people suffer from hunger, lack of drinking water and illiteracy. More than $60 \%$ of the world's population has to make do with two or less dollars a day, and more than a hundred countries around the world are worse off than they were 25 years ago. The disparities continue to grow and as the rich and poor grow, the middle class shrinks. Large differences in the distribution of wealth in the world's major regions are best characterized by their financial wealth. The total global wealth reached 351.5 billion at the end of 2017. USD, but then fell to 345.4 billion. USD at the end of 2018. In the middle of 2019, it rose again to 360.6 billion. USD. The negative side of globalization is the growth of population migration, the quality of the environment is deteriorating, and social cohesion or people's solidarity is being threatened. As the globalized world economy is prone to rapid collapse, as evidenced by the current situation, it is also considered a negative phenomenon. 
The fact that globalization has gained momentum is also documented by the KOF Globalization Index (economic dimension, social dimension and political dimension). In 2019 , the most globalized country was Switzerland with a KOF index value of 91.19, the 13th place belongs to the Czech Republic 85.6, the Slovak Republic in the 19th place with the KOF index value of 83.72. Based on the values of the KOF index of the Slovak Republic, we can state that the Slovak economy is more globalized from year to year. While in 1993 the value of the KOF Globalization Index: Economic Dimension was at the level of 57.1 until 2017, it gradually increased to the value of 83.7. As we have already mentioned, a very strongly globalized economy is more prone to global events, which we felt in Slovakia already in 2008. In the current period, when globalization has manifested itself even more significantly, further development of globalization processes will be affected by the current economic crisis and possible retreat from globalization towards national economies. It will be necessary to shorten supply chains and ensure the production of basic goods for the people of one's own country, and it is therefore necessary to take measures to build up strategic reserves of basic goods, as the pandemic has revealed that international production networks are vulnerable. Indeed, several multinational companies are considering repatriating part of their production capacity to their home countries, and the WTO expects foreign direct investment to fall by as much as $30-40 \%$ in $2020 / 21$. World trade flows could fall by as much as a third this year. The International Monetary Fund (IMF) predicts the sharpest economic decline in world real GDP (-3\% in 2020), which will be much worse than in the case of the global financial crisis of 2009. The cumulative loss of world GDP due to the pandemic crisis could in 2020 and 2021 represent about \$ 9 trillion (IMF, World Economic Outlook, April 2020).

Globalization has affected all economic actors. In this article, we will focus on Slovak households, because, like households around the world, they have been affected by globalization processes or innovative changes. We focused on new challenges also affected by the arrival of foreign investors with job offers, changes in income, or the structure of household expenditures.

\section{Methodology}

We are currently witnessing that households and their income situation is not favorable. Many consumers around the world are facing sudden pressure to meet the basic needs of the Maslow pyramid. The research topic in the scientific article is the issue of households, household economics in the context of globalization processes. The research problem is the analysis of the obtained data in the context of examining the income situation of Slovak households as well as the analysis of their expenditures. Through a theoretical analysis of domestic and foreign sources, we have defined globalization as a historical process of connecting economies and its impact on the behavior of its subjects.

For the analysis, we used the database The KOF Globalization Index measures the economic, social and political dimensions of globalization. Globalization in the economic, social and political fields has been on the rise since the 1970s, receiving a particular boost after the end of the Cold War [18]. 2019 KOF Globalization Index: Economic Dimension, data Cube, Eurostat, EU SILC (EU-Statistics on Income and Living Conditions), COICOP. In our empirical part, we used correlation analysis to examine the relationship between gross disposable income, household income, gross household savings and household final consumption, the development of the average wage in the Slovak Republic \% and the development of final consumption expenditure - households (\%). In the empirical part, we also analyzed individual expenditure categories of households.

The correlation coefficient $\mathrm{r}(\mathrm{x}, \mathrm{y})$ expresses the relationship for a pair of quantities $\mathrm{x}$ and $y$. It requires the expression of the combination of the mean and variance that 
characterizes the behavior of each of the variables. This connection is expressed by statistical covariance $-\mathrm{k}(\mathrm{x}, \mathrm{y}), \operatorname{cov}(\mathrm{x}, \mathrm{y})$ :

$$
k(x, y)=\frac{1}{n-1} \sum_{i=1}^{n}\left(x_{i}-\bar{x}\right)\left(y_{i}-\bar{y}\right)
$$

If we know $\mathrm{k}(\mathrm{x}, \mathrm{y})$, then we calculate the correlation coefficient:

$$
r(x, y)=\frac{k(x, y)}{s_{x} s_{y}}
$$

The value of the correlation coefficient expresses a linear measure of the dependence of $\mathrm{x}$ and $\mathrm{y}$. Its value takes values from -1 to 1 . From the findings, we formulated conclusions based on the examined indicators.

\section{Results and Discussions}

Globalization affects the behavior of all economic subjects. Households and their economies are affected by current globalization processes and innovative changes. Household economics as an economic discipline examines the ability of households that jointly own property to use income and make economic decisions. It also examines the ability of households to secure income to meet their needs, to manage in order to maintain the required quality of life. It is income inequality that is associated with globalization. In the Slovak Republic, as the economy was significantly undercapitalised, there was gradually room for the arrival of many foreign companies that supported business start-ups and created new jobs in almost all sectors of the economy, which had a positive effect on wages.

On the other hand, they competed with domestic companies, and many of them gradually disappeared, which in turn affected unemployment. As wages rise, so did consumption, consumption patterns changed as households wanted to meet their needs and improve their quality of life. Understanding household consumption habits lies in understanding human behavior. Consumer habits today in the Slovak Republic are very different from the habits of 30 years ago. They are also significantly affected by globalization processes, for example through foreign direct investment, which has brought revolutionary innovations and new job opportunities to our economy, which has contributed to rising wages, thus opening up new opportunities for raising the living standards of the population. The standard of living is one of the determinants of quality of life and an important component of quality of life is consumption, which depends on income [19]. In the Slovak Republic, household income increased mainly in regions where foreign investors were established. Foreign direct investment went mainly to the Bratislava region, less to the Trnava, Nitra and Žilina regions, and minimal volumes went to the Prešov and Banská Bystrica regions (Fig. 1). The direction of FDI was influenced by the conditions that the regions were able to provide to foreign investors, educational level, qualified workforce with the required qualification structure, the state of infrastructure, accessibility in terms of markets and much more. 


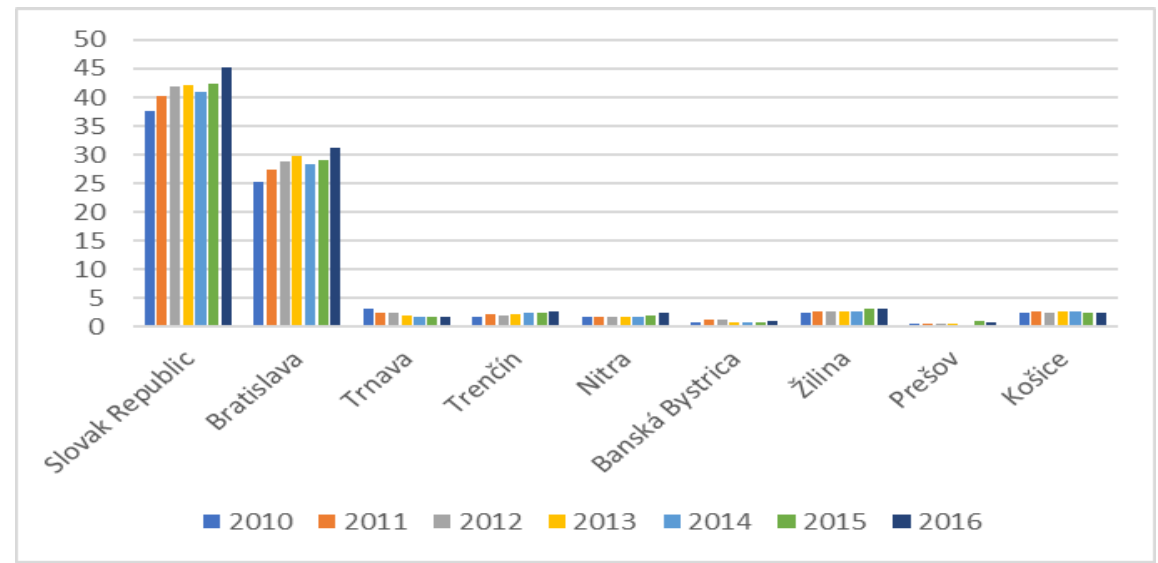

Fig. 1. State of foreign direct investment in the Slovak Republic and regions $(€)$

Developments in the labor market were reflected in the growth of average wages, disposable household income and gross savings. From 1995 to 2020, they grew cumulatively (Fig. 2). From 1995, gross household savings gradually increased until 2004, when gross savings declined. The indicator of gross disposable income of households copied this development, with the exception of 2009, when it occurred as a result of the economic crisis.

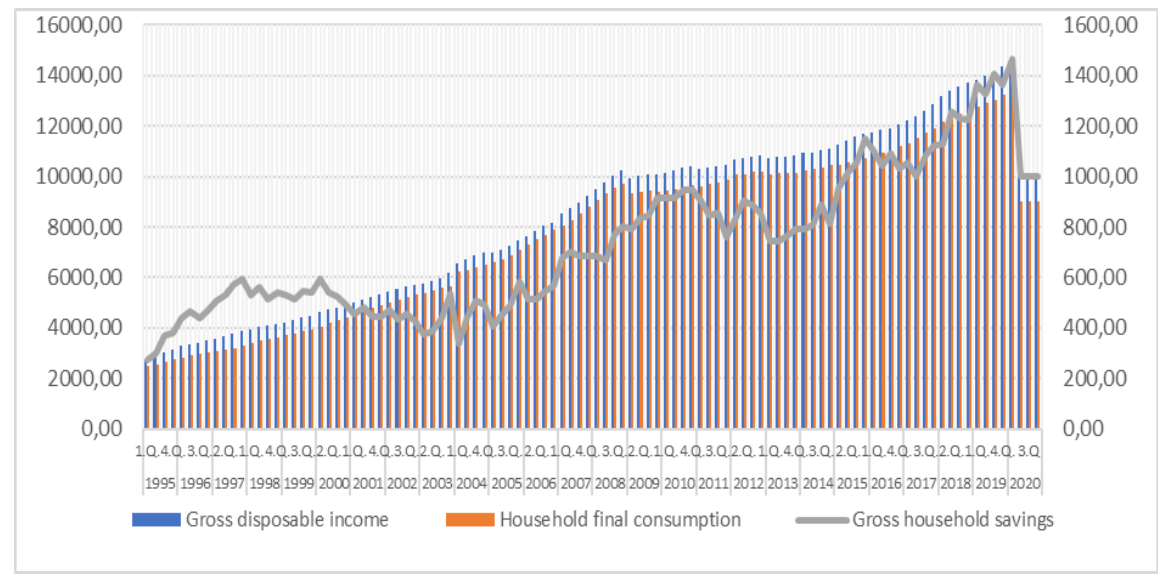

Fig. 2. Development of household final consumption, gross disposable income and gross household savings (in the Slovak Republic, mil. €)

Based on the regional analysis of net cash income of households in the Slovak Republic, net cash income of households ( $€$ / person / month) in the Bratislava Region was above the Slovak average throughout the period under review, which is also related to foreign investors as mentioned above. From 2006 to 2018, both households and households in the Trnava Region achieved a higher level of net cash income than the Slovak average. Since 2010, households in the Trenčín Region have also been above the Slovak average. Households in the Prešov and Košice regions achieved a lower level of net cash income than the Slovak average.

The growth of disposable income was also influenced by the development of household final consumption in order to satisfy the needs of household members. The interdependence between gross disposable income, household income, gross household savings and household final consumption is also confirmed by the values of correlation coefficients. 
The value of the correlation coefficient between gross disposable income and final consumption reached the value is 0.999094055 , which represents a strong dependence. There is also a strong dependence between household final consumption and gross savings 0.895462039 and gross disposable income of households and gross household savings 0.912141689. Based on data from the Slovak Statistical Office of the Slovak Republic, we analyzed household final consumption expenditure from 1995 to 2020.

In 2010, final consumption of households decreased - 1.99\%, in 2007 an increase of $7.44 \%$ was recorded, in 2019 there was an increase of $2 \%$. Despite the fluctuations, the increase in final consumption of households in the Slovak Republic from 1995 to 2019 was on the one hand due to economic growth, but above all it was an increase in average income and a change in the price level of some products, especially consumer electronics and clothing. We can state that globalization has also had an impact on the positive development of the examined indicators and economic growth.

In 2020, there was a decline in consumption due to the economic crisis. In March 2020, in Slovakia, $54 \%$ of households began to reduce their expenditures in a targeted manner, because already in the first half of 2020, average wages fell, which had developed positively in the Slovak Republic since 1995 . Growth was affected by several factors. From 2000 to 2002 they also grew due to the inflow of foreign capital, in 2003 there was a decrease. Subsequently, they grew until 2009, when due to the economic crisis, their growth fell to 2013, then they grew until 2019, and we recorded a decline again in the first quarter of 2020. Figure 3 shows the year-on-year development of final consumption, which copies the development of average wages; by correlation analysis, we found that there is a slight dependence of 0.69855 between the development of the average wage and household final consumption.

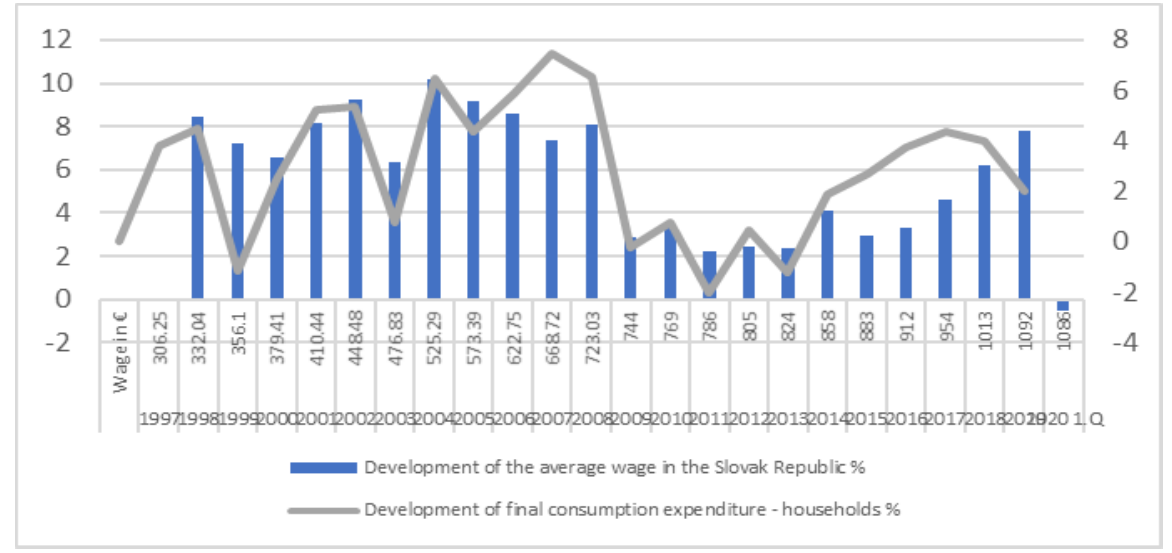

Fig. 3. Development of the average wage and final consumption in the Slovak Republic

As we have already mentioned, households use their income for consumption and the related satisfaction of household needs. Globalization and international trade for consumers eliminate or reduce import tariffs on goods and services, resulting in lower prices. In addition, consumers have more choice. The average European consumer has saved around $€ 600$ a year thanks to lower prices and more choice. Globalization also helps to increase wealth, comfort and living standards. European countries also trade with each other. The aim of the single market is to remove all trade barriers within the EU. The European single market is the largest duty-free economic area in the world. This area covers more than half a billion citizens and generates a GDP of $€ 13$ trillion [20].

Globalization has also affected Slovak consumers in this way. We recorded a decrease in expenditures as early as mid-April in 2020, up to $64 \%$, which is expected to increase the 
savings rate. This is a typical phenomenon in times of pandemics, when households tend to start saving because on the one hand they have nowhere to spend, on the other hand they are afraid to spend their income due to uncertainty and fears about the future. Concerns about the future are also caused by the fact that at present every third adult citizen of the Slovak Republic is in debt, in contrast to the financial crisis in 2008-2009, when debt did not play such a big role in favor of savings, because household indebtedness was still low. Indebtedness in relation to income has almost doubled. If in 2010 the household indebtedness was around 32 billion $€$, in 2019 it was about 51 billion $€$, with $70 \%$ of total household debt being mortgage debt. Many have called for deferred payments due to loss of income, and consequently households working in sectors affected by the economic crisis or affecting many households in the future will consider whether they will consume or tend to make savings.

The reason for increasing indebtedness is high housing expenditures, which we find out by analyzing household expenditures using the COICOP-HBS classification, which was used in the Slovak Republic and European Union countries from 1997 to 2014 and since 2015 is the valid COICOP-5 classification. expenditure categories. In terms of meeting needs, we can divide expenditures into 2 basic groups: 1 . consumer expenditures expenditures for goods and services (i.e. all departments 01 to 12 of the COICOP-5 classification) and 2. other expenditures - other payments. Expenditures are intended for the consumption of long-term goods (washing machines, cars, players), the consumption of short-term goods (food, clothing, petrol) and the consumption of services (barber, healthcare, education).

The development of the shares of net monetary expenditures in total household expenditures is also monitored by type of household (households of employees, households of pensioners and households of self-employed persons). The shares of net monetary expenditures of individual goods and services in total expenditures change in the observed period. The share of net monetary expenditures on individual goods and services in total expenditures not only documents the different level in household consumption of employees, self-employed person and pensioners, but also provides an overview of changes in the consumption of individual households during the period under review. We focused on examining the net monetary expenditure of employees' households, which developed differently in some items from 2004 to 2018.

Slovak households have long had the highest expenditures on housing and food, while in 2018, for example, expenditures on housing accounted for up to $27.7 \%$, expenditures on food for $17.4 \%, 9.4 \%$ for expenditures on various goods and services. The least expenditures went to education $1.5 \%$ and health only $2.4 \%$, which may be caused mainly by high expenditures on housing. It is well known that the only precondition for the development of society is an increase in expenditure on education. The opposite situation has a negative impact on the development of society as a whole and, indeed, on the income situation in the household. If the household cannot afford to satisfy its needs, it is a manifestation of material and social deprivation work [21]. Education is not only a source of higher income, but also benefits that gradually increase with age [22]. When comparing the wages of employees with basic education, secondary and higher education, we see that the average wage is closest to employees with higher vocational education, above the average gross monthly wage of the Slovak Republic they are employees with higher education.

A more detailed analysis found that there are households in Slovakia that have great difficulty getting money, which is related to the level of household income and currently the situation is deteriorating due to the pandemic crisis, as mentioned above. The most endangered are households of individuals with dependent children, households of families with small children, which can be identified in Fig. 4, which we constructed from the data 
datacube Statistic. Households are unable to secure income, they often rely on state aid and are unable to meet the basic needs of their members from the income they receive.

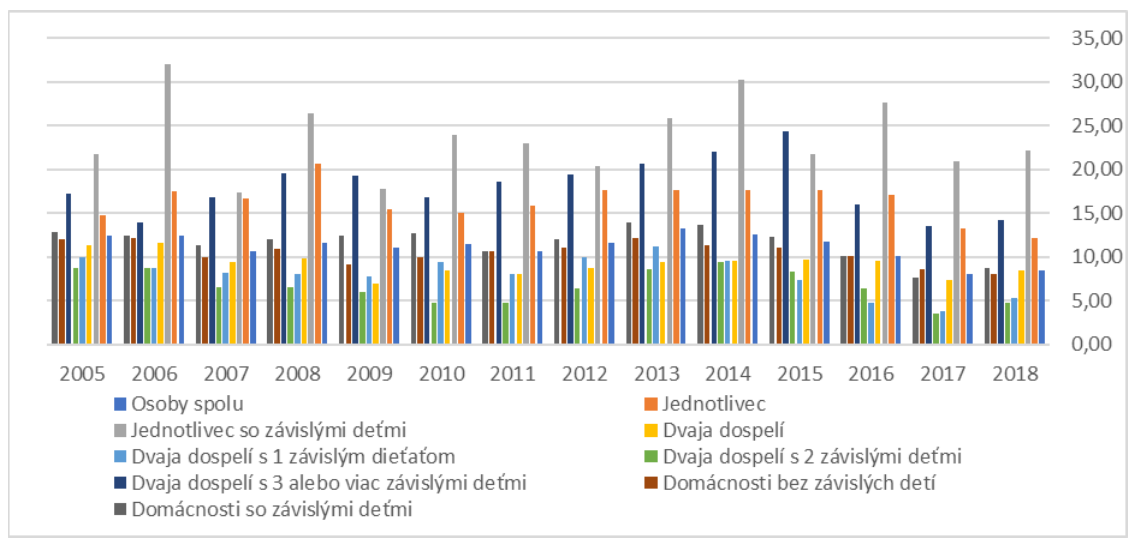

Fig. 4 Proportion of population living in households that have great difficulty coming out with money (\%)

The concentration of the population who are unable to secure their incomes is high, especially in the less developed regions, the Košice Region, the Banská Bystrica Region and the Prešov Region. These are regions where the share of foreign direct investment is low and in general we encounter a lack of job opportunities in these regions and the fact that many have migrated to work in other regions of Slovakia. Another reason is the share of free labor with completed education. When we look at the map of the share of free labor force with incomplete basic education ISCED 0-2, we see that in Slovakia it is the regions in the Košice Region, the Banská Bystrica Region and the Prešov Region, where this share is higher than $50 \%$ in some districts. The untapped potential of less developed regions is also the relatively low activity of the population in comparison with the remaining population or other countries in the region. The gradual overheating of the labor market is reflected in the growing shortage of skilled workers, as the long-term unemployed suffer from a skills shortage [23].

We compared the development of the registered unemployment rate in selected districts of less developed regions (Fig. 5). In the long run, there are high unemployment rates in the districts of the Košice, Prešov and Banská Bystrica regions.

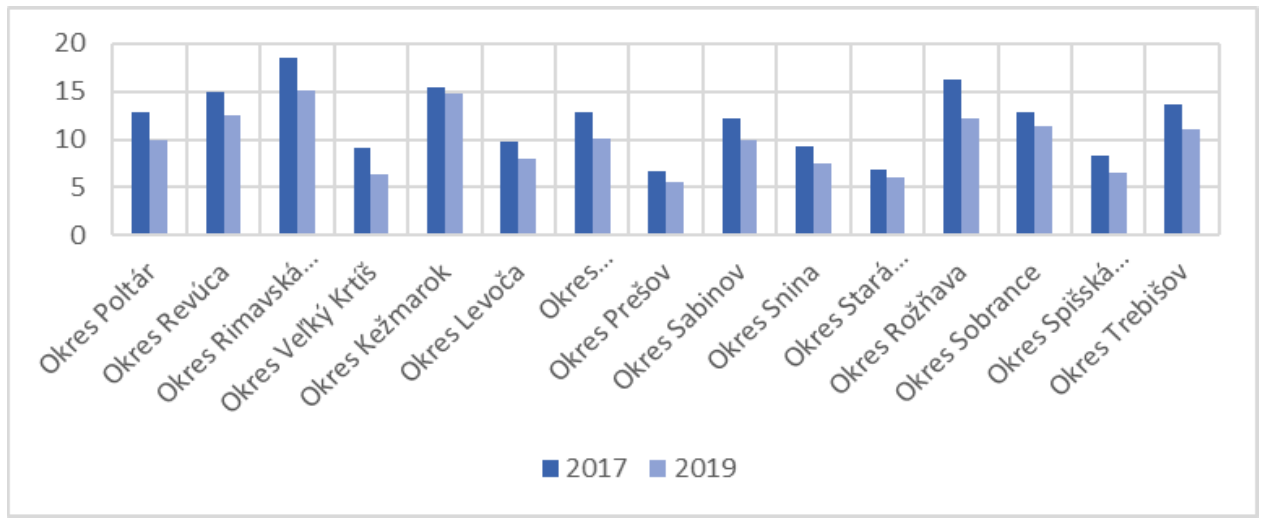

Fig. 5 Development of the registered unemployment rate in selected less developed districts of Slovakia (in\%). [24] 
In 2019 in Rimavská Sobota 15.14\% (18.48\%), Revúca 12.58\% (14.88\%), Kežmarok 14.79\% (15.44\%), Rožňava 12.14\% (16.23\%), Sobrance 11.35\% (12.93\%), Medzilaborce $10.07 \%,(12.83 \%)$. In these districts, more than $35 \%$ of the population has basic education (districts in the east and south of Slovakia (Kežmarok, Námestovo, Revúca, Rimavská Sobota, Rožňava, Poltár, Gelnica, Košice - surroundings) and only 5\% of the population has a university degree (districts Košice - surroundings, Námestovo, Poltár, Bytča, Gelnica, Čadca, Sabinov, Vel'ký Krtíš). The educational level of the population in these regions is related to the higher concentration of Roma population (districts Lučenec, Rimavská Sobota, Poltár, Revúca, Rožňava, Košice Kežmarok).

Every fourth jobseeker has not worked in these districts for more than four years. They are mainly low-skilled employees with the lowest level of education. This combination contributes to weak economic growth, as evidenced by the growth of the registered unemployment rate in selected less developed regions.

\section{Conclusions}

Households are an important entity for the modern economy. In order to be able to fulfill their functions, they must respond to societal developments, which are largely caused by globalization processes. Globalization has brought to our country the benefits that households feel. No generation before us had such good access to food, clothing, technology, health care or the opportunity to travel, work abroad, which contributed to raising living standards, and the purchasing power of lower-income households. Globalization is also associated with risks, unfair behavior, social dumping. Therefore, it is necessary to increase the protection of our citizens in our own country through a strong social policy, to ensure quality education at primary, secondary or higher education institutions. It is essential to focus on lifelong learning and training so that everyone can prepare for the new shape of the labor market brought about by innovation, automation or digitalisation. They have ensured a sufficient income for the population and avoided the pitfalls of social exclusion or other problems. An educated person has disproportionately more chances to enter the labor market and be better valued, so it should be paramount to protect the well-being of children, which is a key factor in their quality of life in adulthood, how high their income will be and their health.

The paper is the output of the research grant VEGA no. 1/0251/19 "Households investments in housing and the possibility of their alternative use as additional income at the time of receiving the pension benefit".

\section{References}

1. Kim, M., Lampert, C.M., Roy, R. (2020). Regionalization of R\&D activities: (Dis)economies of interdependence and inventive performance. Journal of International Business Studies, 51(7), 1054-1075.

2. Jeong, Y., Siegel, J.I. (2020). How important is regional vs. global scope? An examination of U.S. multinationals. Journal of International Business Studies, 51(7), 1142-1160.

3. Sargen N.P. (2018). Globalization and Widening Income Inequality. In: Investing in the Trump Era. Palgrave Macmillan, Cham.

4. Duttagupta R., Lizarazo R.S., Martinez, L.A., Mendes, T.M. (2018). Globalization and Inclusive Growth: Can They Go Hand in Hand in Developing Countries? In L. Paganetto (Ed.). Getting Globalization Right. Springer, Cham. 
5. $\mathrm{Xu}, \mathrm{M}$. (2020). Globalization, the skill premium, and income distribution: the role of selection into entrepreneurship. Review of World Economics, 156(7), 633-668.

6. Bendl, S. (2001). Globalizace a její důsledky pro chování člověka. Pedagogické spektrum, 10(7-8).

7. Bertalanffy, L. (1972). Člověk-robot a myšlení, psychologie v moderním světe. Praha: Svoboda.

8. Samuelson, J. R. (1998, April 9). Svet aký sme nepoznali. Globalizácia je prosperita. Literárny týždeník.

9. Lysák, L. (1997). Globalizácia a zachovanie identity národných a štátnych záujmov. Slovenská republika.

10. Giddens, A. (1990). The Consequences of Modernity. Stanford University Press: Stanford, CT.

11. Gray, J. (2002). Marné iluze. Falešné představy globálního kapitalizmu. Košice: Paradigma.sk.

12. Haggett, P. (2001). Geography a Global Synthesis. Prentice Hall.

13. Pichanič, M. (2004). Mezinárodni management a globalizace. Praha: C. H. BECK PRO PRAXI.

14. Holton, R. (2006). Globalizace. In A. Harrington et al. (Eds.). Moderní sociální teorie, (pp. 385-410). Portál, Praha.

15. Castañeda, E., Shemesh, A. (2020). Overselling Globalization: The Misleading Conflation of Economic Globalization and Immigration, and the Subsequent Backlash. Social Scienes, 9(5), 1-31.

16. Camacho-Beltrán, E. (2019). Legitimate Exclusion of Would-Be Immigrants: A View from Global Ethics and the Ethics of International Relations. Social Sciences, 8(8), Art. No. 238.

17. Piketty, T., Saez, E. (2003). Income Inequality in the United States, 1913 - 1998. The Quarterly Journal of Economics, 118(1), 1-41.

18. KOF Globalisation Index. (2019). ETH Zurich KOF. Retrieved from: https://kof.ethz.ch/en/forecasts-and-indicators/indicators/kof-globalisation-index.html

19. Vidová, J. (2019). Households as an Important Part of the Circular Economy. Waste Forum, 12(3), 178-186.

20. Globalizácia: hlavné benefity a fakty. (2019, June 11). Europsky parlament. Retrieved from: https://www.europarl.europa.eu/news/sk/headlines/economy/20190603STO5352 0/globalizacia-hlavne-benefity-a-fakty

21. Kusá, Z. (2018). Chudoba detí do 18 rokov je dvakrát vyššia ako vo zvyšku populácie. Retrieved from: https://domov.sme.sk/c/20839584/chudoba-socialny-systemmedzinarodny-den-deti.html

22. McCartan, C., Morrison, A., Bunting, L., Davidson, G., McIlroy, J. (2018). Stripping the Wallpaper of Practice: Empowering Social Workers to Tackle Poverty. Social. Scienes. 7(10), Art. No. 193.

23. Sika, P., Vidová, J., Rievajová, E. (2020). Regional View on Housing of the Marginalized Roma Population in the Slovak Republic. Sustainability, 12(14), Art. No. 5597.

24. Štatistický úrad Slovenskej republiky. Retrieved from: http://statdat.statistics.sk/ 